\title{
Varisela pada Dewasa, Kehamilan, dan Kondisi Imunokompromais
}

\section{Mikhael San Putra Wijanarko}

\author{
Fakultas Kedokteran dan Ilmu Kesehatan, Universitas Kristen Krida Wacana, \\ Jakarta, Indonesia \\ Alamat Korespondensi: mikhael.san@gmail.com
}

\begin{abstract}
Abstrak
Varisela merupakan eksantema vesikular yang sangat menular akibat infeksi akut primer eksogen dari virus varisela zoster pada individu yang rentan. Varisela lebih sering menyerang anak-anak dengan usia kurang dari 10 tahun. Tinjauan pustaka ini bertujuan untuk mengetahui kondisi klinis dan terapi varisela pada dewasa, kehamilan dan kondisi imunokompromais. Pada dewasa, varisela biasanya lebih berat dengan mortalitas yang lebih tinggi dibandingkan anak-anak, dimana transmisi yang terjadi melalui droplet atau aerosol dari saluran napas. Masa inkubasinya berkisar antara 10-21 hari. Gejala diawali oleh fase prodromal, kemudian terjadi erupsi kulit yang polimorfik dengan progresifitasnya yang cepat. Pemeriksaan penunjang dapat berupa pemeriksaan Tzank smear, polymerase chain reaction, kultur, dan lain-lain. Varisela pada kehamilan akan mengancam kesehatan ibu dan janin, sedangkan pada pasien imunokompromais, morbiditas dan mortalitas akibat varisela meningkat. Pneumonia varisela merupakan komplikasi varisela yang serius pada dewasa. Pengobatan menggunakan antivirus asiklovir, valasiklovir, dan famsiklovir. Pencegahan dapat dilakukan dengan vaksinasi, varicella zoster immunoglobuline, dan terapi antivirus profilaksis, sehingga pengobatan yang tepat dan upaya pencegahan dengan vaksinasi pada kelompok dewasa yang rentan perlu dilakukan.
\end{abstract}

Kata kunci : cacar air, dewasa, varisela

\section{Varicella in Adults, Pregnancy, and Immunocompromised Conditions}

\begin{abstract}
Varicella is a very contagious vesicular exanthema caused by primary exogenous infection of varicella zoster virus which affects susceptible individuals. Varicella more commonly affects children of less than 10 years old. The literature review aims to understand the clinical conditions and treatment of varicella in adults, pregnancy, and immunocompromised conditions. In adults, varicella is usually more severe and has a higher mortality rate than in children. The transmission is from droplets or aerosols from the respiratory tract. The incubation period ranges from 10 - 21 days. Early symptoms begin with prodromal phase then followed by polymorphic skin eruption with fast progression. The supporting investigations include Tzank smear, polymerase chain reaction, and culture. Varicella in pregnancy threatens the health of the mother and the fetus. While in immunocompromised individuals, the morbidity and mortality of varicella increase. Varicella pneumonia is a serious complication of varicella infection in adults. Treatment uses antiviral drugs such as acyclovir, valacyclovir, and famciclovir. Prevention can be done by vaccination, varicella zoster immunoglobulin, and prophylactic antiviral medications. Therefore, proper treatment and prevention with vaccination for susceptible adults are required.
\end{abstract}

Keywords : adults, chicken pox, varicella 


\section{Pendahuluan}

Varisela (cacar air, chicken pox) merupakan eksantema vesikular yang sangat menular akibat infeksi akut primer eksogen dari virus varisela zoster (VVZ) pada individu yang rentan, yang mengenai kulit dan mukosa, dengan manifestasi klinis berupa gejala konstitusi, kelainan kulit polimorfik terutama di sentral tubuh. ${ }^{1-3}$ Pada anak-anak varisela biasanya bersifat swasirna, tetapi pada dewasa biasanya lebih berat. ${ }^{4,5}$ Tujuan dari pembuatan artikel tinjauan pustaka ini adalah untuk mengetahui kondisi klinis dan terapi varisela pada populasi dewasa serta populasi khusus yaitu kehamilan dan kondisi imunokompromais.

\section{Etiopatogenesis}

VVZ adalah $\alpha$-herpes virus (famili herpesviridae), hanya memiliki satu serotipe. ${ }^{1-4}$ VVZ merupakan virus DNA berantai ganda (di dalam nukleokapsid), memiliki membran luar (amplop ikosahedral) dengan tonjolan glikoprotein sebagai target imunitas humoral dan selular. ${ }^{1,3,6}$ Manusia merupakan satu-satunya reservoir yang diketahui. $^{3} \quad$ Setelah infeksi primer yang menimbulkan varisela, virus neurotropik ini akan menjadi laten di radiks ganglia dorsalis posterior, dan bila terjadi reaktivasi endogen beberapa tahun setelah infeksi awal, akan menimbulkan herpes zoster (HZ). ${ }^{1,7,8}$

Transmisi varisela terjadi secara airborn melalui droplet atau aerosol dari saluran napas, dan dapat juga melalui kontak langsung dengan cairan vesikel, konjungtiva, atau saliva. ${ }^{1,2,8} \mathrm{VVZ}$ masuk melalui mukosa saluran napas atas dan orofaring, kemudian menginfeksi kelenjar getah bening regional (sel T tonsillar). ${ }^{2,8}$ Masa inkubasi berkisar antara 10-21 hari. ${ }^{8}$ Viremia primer terjadi pada awal masa inkubasi, setelah virus menyebar melalui vaskuler dan limfatik (4-6 hari setelah infeksi). ${ }^{1,2,8}$ Sel $\mathrm{T}$ yang terinfeksi akan membawa virus ke sistem retikuloendotelial (tempat utama repliaksi virus selama masa inkubasi) dan kulit. ${ }^{2}$ Eliminasi virus dilakukan oleh imunitas non spesifik (interferon dan sel natural killer) dan spesifik, dan apabila proses ini gagal maka akan terjadi viremia sekunder dalam 10-14 hari setelah infeksi. ${ }^{1,2,8}$ Viremia sekunder akan menimbulkan erupsi varisela terutama di sentral tubuh. ${ }^{1}$ Pada kulit, VVZ menginfeksi sel epitel stratum basal dan stratum spinosum. ${ }^{2}$ Infeksi ini akan menghasilkan lesi papular, yang akan berubah menjadi vesikel intraepitel dalam 12-24 jam, akibat meningkatnya sel epitel yang terinfeksi. ${ }^{2}$ Pada kasus tanpa komplikasi, infeksi subklinis terjadi pada banyak organ. ${ }^{2}$ Dalam 3-5 hari, viremia akan diakhiri oleh respon imun spesifik VVZ (dimediasi oleh sel T). ${ }^{2}$ Pasien menjadi infeksius 1-2 hari sebelum eksantem muncul hingga 4-5 hari kemudian (kelompok vesikel terakhir menjadi krusta)., ${ }^{2,3,8}$ Krusta dari lesi kulit tidak infeksius. ${ }^{2}$ Infeksi varisela akan menimbulkan kekebalan seumur hidup. $^{2}$

\section{Varisela pada Dewasa}

Varisela sangat menular dengan tingkat serangan sebesar $70-90 \%$ pada individu yang rentan (seronegatif). ${ }^{3,9}$ Virus ini tersebar diseluruh dunia dan dapat mengenai laki-laki maupun perempuan, serta semua ras. ${ }^{1-3}$ Penyakit ini lebih sering menyerang anak-anak dengan usia $<10$ tahun $(90 \%){ }^{2}$ Infeksi pada dewasa biasanya lebih berat (risiko rawat inap sebesar 13-16 kali lipat) dan lebih tinggi mortalitasnya (25-40 kali lipat) dibandingkan anak-anak. ${ }^{7,9,10}$ Pada daerah dengan iklim tropis dan subtropis, kerentanan terhadap varisela pada kelompok usia dewasa sangat signifikan. ${ }^{2,6}$

Secara serologis, imunitas terhadap VVZ pada dewasa mencapai nilai 90\%. ${ }^{11}$ Hasil seroepidemiologi pada dewasa menunjukkan nilai $1-7 \%$ yang seronegatif. ${ }^{5}$ Data seroprevalensi imunoglobulin (Ig)G anti VVZ di Eropa menunjukan semua orang sudah pernah mengalami serokonversi sebelum usia dewasa. ${ }^{12}$ Serokonversi di negara-negara Asia beriklim tropis terjadi pada usia yang lebih tua, sehingga menimbulkan risiko morbiditas dan mortalitas yang lebih tinggi. ${ }^{9}$ Data di Bangkok, Thailand menunjukan serokoversi sebesar $98-100 \%$ pada usia 40 tahun. ${ }^{4}$ Data di Singapura pada kelompok usia diatas 25 tahun, didapatkan serokoversi sebesar $88 \%$ pada periode tahun 1990-2010. ${ }^{4}$ Penelitian di Poli Kulit Kelamin RSUP Prof D. R. Kandou Manado tahun 2015, menemukan $33,3 \%$ kasus varisela terjadi pada kelompok usia 15-24 tahun. ${ }^{6}$

Sebelum era vaksinasi, pada tahun 19881995 di Amerika Serikat, didapatkan risiko rawat inap dan kematian akibat varisela, lebih tinggi pada dewasa yang sebelumnya tampak sehat. ${ }^{2}$ Setelah era vaksinasi, terjadi penurunan insiden, termasuk di kelompok usia dewasa yang bukan merupakan kelompok usia target vaksinasi. ${ }^{2}$ Insiden varisela pada dewasa menurun hingga sebesar $82 \% .{ }^{11}$

Gejala varisela diawali oleh fase prodromal, 1-3 hari sebelum erupsi kulit, berupa demam yang tidak terlalu tinggi, nyeri kepala, malaise, anoreksia, nyeri tenggorokan, batuk, dan lainlain. ${ }^{1-3}$ Erupsi kulit pada pasien yang tidak 
tervaksinasi biasanya bermula di wajah dan kulit kepala, kemudian menyebar secara cepat ke badan, dan menyisihkan ekskremitas. ${ }^{2}$ Lesi baru bermunculan terus menerus dalam suatu kumpulan yang terdistribusi dibagian sentral. ${ }^{2}$ Lesi lebih padat diantara skapula, dan bagian medial dari lengan dan tungkai, serta dapat muncul lebih awal dalam jumlah besar di daerah inflamasi (sunburn), dan tidak jarang di telapak tangan-kaki. ${ }^{2}$

Karateristik lesi adalah progresifitasnya yang cepat (kurang dari 12 jam). ${ }^{2}$ Berawal dari makula eritema menjadi papul, vesikel, pustul, dan krusta. $^{2}$ Vesikel berbentuk elips seperti tetesan embun (tear drops), berdiameter 2-3mm, pada vesikel awal memiliki dinding tipis yang superfisial dengan dikelilingi bagian eritema yang ireguler (dewdrop on a rose petal). ${ }^{1,2}$ Vesikel akan berubah keruh (akibat peningkatan jumlah leukosit polimorfonuklear, sel-sel degeneratif, dan fibrin) menjadi pustul, kemudian pecah mengeluarkan cairan (mengandung virus yang infeksius) atau mengering yang berawal dari bagian tengah (pustul dengan umbilikasi), lalu menjadi krusta. $^{1-3}$ Sementara proses ini berlangsung, akan timbul vesikel-vesikel baru, sehingga pada satu waktu akan memberikan gambaran polimorfik (lesi tampak dalam semua tahap perkembangan). ${ }^{1,2}$ Mukosa mata, hidung, faring, laring, trakea, mulut, esofagus, traktus gastrointestinal, traktus urinarius, dan vagina dapat terkena. ${ }^{1,2}$ Vesikel di mukosa sangat cepat pecah dan meninggalkan ulkus dangkal. ${ }^{2}$ Pada dewasa, jumlah lesi lebih banyak dibandingkan pada anak-anak. ${ }^{2}$ Demam biasanya menetap selama lesi baru masih muncul, serta lebih menonjol dan memanjang. ${ }^{2}$ Demam yang memanjang atau muncul kembali setelah normal, dapat menunjukan adanya infeksi bakteri atau komplikasi lain. ${ }^{2}$ Keluhan yang sering muncul dan sangat mengganggu adalah rasa gatal yang menetap hingga semua lesi menjadi krusta. ${ }^{1,2}$ Krusta akan terlepas dengan sendirinya setelah 1-3 minggu. ${ }^{2}$ Pembentukan skar dapat terjadi bila lesi mengalami trauma atau superinfeksi bakteri. ${ }^{2}$

\section{Pemeriksaan penunjang}

Pemeriksaan penunjang dilakukan bila kasus yang muncul tidak biasa atau terdapat komplikasi. ${ }^{1,7}$ Beberapa pemeriksaan penunjang yang dapat dilakukan adalah pemeriksaan Tzank smear untuk menemukan adanya sel datia berinti banyak. ${ }^{1}$ Dilakukan dengan cara melakukan kerokan dasar vesikel, dibuat sediaan hapus dengan pewarnaan Giemsa, Hematoxylin Eosin, atau pewaranaan lain. ${ }^{1,2}$ Pemeriksaan ini tidak spesifik dengan sensitivitas sebesar $60 \% .^{1,3}$ Pemeriksaan menggunakan polymerase chain reaction (PCR) merupakan pemeriksaan diagnostik terbaik dengan sensitivitas dan spesifitas yang baik, serta hasil yang cepat (satu hari atau kurang). ${ }^{2}$ Pemeriksaan ini dilakukan untuk mencari DNA VVZ dari cairan vesikel (spesimen terbaik) atau spesimen lain (kerokan lesi, krusta, biopsi jaringan, darah, saliva, atau cairan serebrospinal). ${ }^{1-4}$ PCR dapat membedakan VVZ dari herpes simpleks virus, atau membedakan strain liar dengan strain vaksin Oka. ${ }^{2}$

Pemeriksaan kultur VVZ merupakan baku emas untuk mendiagnosis varisela. ${ }^{4}$ Isolasi virus dapat dilakukan dalam 1-2 hari setelah onset ruam. ${ }^{4}$ Kultur membutuhkan waktu satu minggu atau lebih. ${ }^{2}$ Sensitivitas kultur lebih rendah dibandingkan dengan PCR. ${ }^{7}$ Kultur dapat digunakan untuk menentukan sensitivitas terhadap antivirus. $^{2}$ Spesimen diaspirasi dari vesikel baru dengan cairan yang jernih. ${ }^{2}$ Risiko kegagalan meningkat setelah vesikel menjadi pustul, dan tidak pernah diisolasi dari krusta. ${ }^{2}$ Histopatologi juga dapat dilakukan dimana pada varisela dapat ditemukan akantosis, degenerasi balon, badan inklusi intranuklear eosinofilik (asidofilik), dan sel raksasa berinti banyak (akibat fusi dari sel epitel yang terinfeksi dengan sel disekitarnya). ${ }^{2,3}$ Pada dermis dapat ditemukan edema dan infiltrat sel mononuklear. ${ }^{2}$ Pemeriksaan dengan pewarnaan imunofluoresen atau imunoperoksidase dari materi selular vesikel baru atau prevesikuler dapat mendeteksi VVZ lebih sering dibandingkan dengan kultur. $^{2}$ Pemeriksaan menggunakan enzyme immunoassays dapat mendeteksi antigen VVZ dengan lebih cepat, tetapi sensitivitas dan spesifitasnya lebih rendah dari PCR. ${ }^{2}$

Pemeriksaan serologi digunakan untuk melakukan diagnsosis secara retrospektif dengan membandingkan serum akut dan konvalesen. ${ }^{2}$ Tes ini jarang dilakukan, dan biasanya dilakukan untuk pasien yang rentan dan menjadi kandidat untuk isolasi atau profilaksis. ${ }^{2}$ Pemeriksaan serologis dapat dilakukan dengan solid-phase enzyme-linked immunosorbent assay, fluorescent-antibody to membrane antigen of $V Z V$, atau tes aglutinasi lateks. ${ }^{1,2}$ Beberapa pemeriksaan tambahan lain berupa pemeriksaan darah tepi, dimana dapat ditemukan penurunan leukosit. ${ }^{1}$ Dapat juga terjadi peningkatan sedang pada enzim hepar. ${ }^{1,13}$

\section{Diagnosis Banding}

Penegakan diagnosis dari varisela tidaklah sulit, ruam yang khas dan riwayat paparan akan menuntun ke diagnosis yang tepat. ${ }^{3,7}$ Beberapa diagnosis banding dari varisela yaitu eksantema vesikuler dari virus Coxsackie, Echovirus, dan campak yang atipikal. ${ }^{2,3}$ Biasanya penyakit- 
penyakit ini memiliki lesi yang morbiliformis dengan komponen hemoragik dibandingkan vesikuler mupun vesikopustuler. ${ }^{3} \mathrm{HZ}$ diseminata juga dapat menyerupai varisela bila penyebaran berasal dari area HZ (ganglion saraf yang terkena) yang kecil, tidak nyeri, dan erupsi dermatomal yang kurang nyata. ${ }^{2}$ Sedangkan untuk herpes simpleks diseminata biasanya jarang terjadi dan terbatas pada pasien dengan imunokompromais yang berat. ${ }^{2}$ Lesi biasanya terkonsentrasi dan mengelilingi lokasi infeksi primer atau rekuren (mulut atau genital eksternal), pasien tampak toksik dan terdapat keterlibatan viseral. ${ }^{2}$ Pada variola, klinis lebih berat dengan erupsi kulit bersifat monomorf (semua lesi dalam tahap evolusi yang sama), lesi lebih besar, dengan distribusi dimulai di akral tubuh (telapak tangan dan kaki)., Impetigo, hipersensitivitas gigitan serangga, hand, foot, and mouth disease, dan skabies impeteginisata juga dapat menjadi diagnosis banding. ${ }^{1,2}$

\section{Varisela pada Kehamilan}

Di Amerika Serikat, insiden varisela maternal sebesar 1,21 per 10.000 kehamilan pada tahun 2003 hingga 2010. ${ }^{11}$ Varisela pada kehamilan akan mengancam kesehatan ibu dan janin. ${ }^{2}$ Viremia maternal dapat menimbulkan infeksi intrauterin (transplasental) dan menyebabkan abnormalitas kongenital walaupun pada kasus tanpa komplikasi. ${ }^{2,14}$ Sindrom varisela kongenital ditandai dengan lesi kulit (parut), defek neurologis dan okuler, hipoplasia ekskremitas atau anomali skeletal, serta abnormalitas gastrointestinal, genitourinari, dan kardiovaskular. ${ }^{7,14}$ Sindrom varisela kongenital memiliki risiko $2 \%$ pada usia kehamilan 13-20 minggu. ${ }^{2,7,11}$ Infeksi diseminata dan pneumonia varisela dapat menimbulkan kematian pada ibu. ${ }^{2}$ Pneumonia varisela dapat terjadi pada $10-20 \%$ ibu hamil yang terinfeksi akut, dengan mortalitas (50\%) dan morbiditas lebih tinggi dibandingkan populasi dewasa secara umum. ${ }^{15}$ Risiko meningkat pada usia kehamilan 28 minggu hingga waktu kelahiran. ${ }^{15}$

\section{Varisela pada Kondisi Imunokompromais}

Morbiditas dan mortalitas varisela meningkat pada pasien imunokompromais (akibat penyakit dan obat-obatan seperti kortikosteroid atau kemoterapi untuk kanker). ${ }^{2,7}$ Replikasi virus terjadi terus menerus dan infeksi diseminata menimbulkan viremia yang tinggi dan memanjang, lesi sangat luas, pembentukan vesikel baru yang memanjang, dan keterlibatan viseral yang signifikan. ${ }^{2}$ Lesi yang terus bermunculan hingga satu minggu atau lebih, membuat masa infeksius memanjang. ${ }^{2}$ Lesi biasanya kurang dikelilingi oleh eritema, progresi dari papul menjadi vesikel tertunda atau tidak ada, lesi hemoragik, dan rentan terjadi infeksi bakteri yang berat. ${ }^{2,7}$ Komplikasi viseral dapat terjadi pada $30-50 \%$ kasus dan bersifat fatal pada $15 \%$ kasus bila tidak terdapat terapi antivirus. ${ }^{3}$ Selain itu, dapat terjadi pneumonia, hepatitis akut dan berat dengan gagal organ, ensefalitis, komplikasi hemoragik (purpura ringan hingga fulminan dengan koagulasi intravaskular diseminata). ${ }^{2,5,7,13}$

\section{Komplikasi}

Risiko komplikasi dari varisela bertambah dengan meningkatnya usia, ${ }^{12}$ sehingga lebih sering terjadi pada kasus dewasa dibandingan anakanak. ${ }^{1,2}$ Superinfeksi bakteri (Streptococcus pyogenes dan Staphylococcus aureus) terjadi akibat ekskoriasi pada lesi akibat garukan., ${ }^{1,2}$

Pneumonia varisela merupakan komplikasi varisela yang serius pada dewasa $(20 \%$ kasus). ${ }^{3,11}$ Angka mortalitasnya mencapai $24 \%$ pada pasien dewasa yang imunokompeten. ${ }^{16}$ Faktor risikonya dapat terjadi pada laki-laki, kehamilan, riwayat penyakit paru, merokok, imunokompromais, dan memiliki lebih dari 100 lesi. ${ }^{8}{ }^{11,16}$ Makrofag alveolus dapat menjadi rentan terhadap infeksi virus akibat merokok. ${ }^{17}$ Gejalanya berupa batuk kering, dispnea, takipnea, demam tinggi, nyeri dada pleuritik, sianosis, dan hemoptsis pada 1-6 hari serelah onset ruam. ${ }^{2,3,8,11}$ Ditemukan pula angka yang tinggi terjadinya gagal napas. ${ }^{8}$ Pemeriksaan pencitraan memperlihatkan densitas noduler difus peribronkial (seperti pneumonia virus lainnya) diseluruh lapang paru dan dapat ditemukan pneumonitis interstisial. ${ }^{2,3,11}$

Komplikasi pada mata dapat terjadi akibat replikasi VVZ ataupun reaksi imunitas akibat infeksi virus, yang terbentuk dalam beberapa hari hingga minggu setelah ruam kulit muncul. ${ }^{18}$ Manifestasi yang muncul dapat bervariasi seperti konjungtivitis, keratitis, uveitis anterior, vasukilitis retina, korioretinitis, neuritis optik, dan lain-lain. ${ }^{18}$ Beberapa komplikasi lainnya adalah ensefalitis, glomerulonephritis, miokarditis, hepatitis, otitis, orkitis, pankreatitis, gastritis, lesi ulseratif di usus, artritis, arteritis dan kelainan darah. ${ }^{1-3}$ Komplikasikomplikasi ini kemungkinan akibat infeksi VVZ di parenkim atau endovaskular. ${ }^{2}$

\section{Tatalaksana}

Pengobatan pada pasien dengan imunitas yang baik ditujukan untuk mencegah terjadinya 
komplikasi. ${ }^{3}$ Tatalaksana secara umum yaitu menjaga higienitas yang baik termasuk mandi setiap hari, melakukan perawatan kulit yang cermat, dan memotong kuku. ${ }^{3}$ Pengobatan secara topikal dapat menggunakan bedak untuk mencegah vesikel pecah terlalu dini, dapat ditambahkan zat anti gatal (mentol, kamfora). ${ }^{1}$ Antivirus topikal tidak memiliki peranan dalam pengobatan varisela. $^{2}$ Antibiotik topikal dapat digunakan bila terdapat infeksi sekunder. ${ }^{1}$ Pengobatan secara sistemik berupa antivirus analog nukleosida (analog guanosin) yaitu asiklovir dan pensiklovir. ${ }^{2}$ Valasiklovir (valin ester dari asiklovir) dan famsiklovir (prodrug pensiklovir) diserap lebih baik dan kadarnya dalam darah lebih tinggi, sehingga lebih dipilih dalam terapi varisela dibandingkan asiklovir. ${ }^{2}$ Pemberian terapi dalam 24 jam setelah onset akan mengurangi waktu pembentukan krusta, tingkat penyakit, durasi gejala dan demam. ${ }^{2}$ Dosis yang dapat diberikan pada remaja $(\geq 40 \mathrm{~kg})$ dan dewasa adalah valasiklovir $1 \mathrm{~g}$ per oral (po) setiap 8 jam selama 7 hari, atau famsiklovir $500 \mathrm{mg}$ po setiap 8 jam selama 7 hari, atau asiklovir $800 \mathrm{mg}$ po $5 \mathrm{kali} /$ hari selama 7 hari. $^{2,3}$ Lini kedua adalah foskarnet (analog pirofosfat) terutama untuk kasus VVZ yang resisten terhadap nukleosida. ${ }^{2}$ Lini ketiga adalah cidofovir. $^{2}$ Pada kasus dengan komplikasi pneumonia, dapat diberikan asiklovir (dalam 36 jam masuk rawat inap) $10-15 \mathrm{mg} / \mathrm{kgBB}$ intravena (iv) setiap 8 jam selama 7-10 hari serta bantuan respirasi. ${ }^{2,11,16}$ Komplikasi lain seperti ensefalitis, meningoensefalits, mielitis, dan kompilkasi okular juga diterapi dengan asiklovir iv. ${ }^{2}$ Sedangkan terapi simptomatik dapat berupa antipiretik analgesik dan antihistamin (dengan efek sedatif ataupun sedatif) untuk pruritus. ${ }^{1,2}$ Antibiotik oral dapat diberikan bila terdapat infeksi sekunder. ${ }^{1}$

Penggunaan asiklovir secara rutin pada ibu hamil dengan varisela tanpa komplikasi tidak dianjurkan, karena risiko pada janin tidak diketahui. ${ }^{2}$ Pemberian terapi direkomendasikan bila ruam sangat ekstensif, tampak toksik, tanda infeksi sistemik, dan adanya faktor risiko (pengobatan imunosupresif). ${ }^{2}$ Beberapa ahli merekomendasikan pemberian asiklovir pada trimester ketiga (organogenesis sudah selesai) dan bila ada risiko penyebaran infeksi ke neonatus dan pneumonia varisela. Terapi pneumonia seperti rekomendasi pada pasien dewasa. ${ }^{2}$

Pada kasus imunokompromais yang ringan atau dengan varisela ringan dapat diberikan valasiklovir $1 \mathrm{~g}$ po setiap 8 jam selama 7-10 hari, atau famsiklovir $500 \mathrm{mg}$ po setiap 8 jam selama 710 hari, atau asiklovir $800 \mathrm{mg}$ po $5 \mathrm{kali} / \mathrm{hari}$ selama 7-10 hari. ${ }^{2,3}$ Pada kasus varisela berat atau imunokompromais berat dapat diberikan asiklovir
$10 \mathrm{mg} / \mathrm{kgBB}$ iv setiap 8 jam selama 7-10 hari. $^{2,3}$ Pemberian asiklovir iv dalam 72 jam setelah onset ruam, dapat menurunkan insiden komplikasi viseral yang mengancam nyawa. ${ }^{2}$ Bila lesi baru sudah tidak muncul kembali dan pasien tampak stabil, pemberian asiklovir iv dapat diganti dengan po. ${ }^{2} \mathrm{VVZ}$ yang resisten pada asiklovir ditemukan pada kasus imunokompromias yang berat (AIDS tahap lanjut). ${ }^{2}$ Mekanismenya berupa mutasi gen timidin kinase, sehingga terjadi resistensi silang terhadap gansiklovir, valasiklovir, famsiklovir, dan pensiklovir. ${ }^{2}$ Pasien biasanya berespon dengan penggunaan foskanet dan amenamevir. ${ }^{2}$

\section{Pencegahan}

Vaksinasi dengan virus hidup (strain Oka), direkomendasikan pada rentang usia > 13 tahun hingga $\geq 65$ tahun yang tidak terbukti pernah mengalami varisela atau tidak memiliki kekebalan terhadap varisela. ${ }^{2,3,11,19}$ Vaksinasi diberikan sebanyak 2 dosis (bulan ke-0 dan 4-8 minggu kemudian). ${ }^{19} \quad$ Serokonversi dari vaksinasi mencapai 98\%. ${ }^{11}$ Vaksinasi terutama dianjurkan untuk semua orang dewasa yang rentan dan berisiko terpapar seperti tenaga kesehatan, kontak rumah tangga yang dapat menularkan ke orang dengan imunokompromais atau ibu hamil yang rentan, orang yang bekerja atau tinggal di lingkungan yang memungkinkan terjadinya penularan, orang yang bekerja atau tinggal di lingkungan yang telah dilaporkan adanya transmisi, wanita usia produktif yang sedang tidak mengandung (tidak boleh hamil minimal empat minggu setelah vaksinasi terakhir) dan postpartum, remaja dan dewasa yang tinggal bersama anakanak, dan wisatawan internasional. ${ }^{2,19,20}$ Untuk pencegahan paska pajanan, vaksinasi dapat diberikan kurang dari tiga hari hingga lima hari setelah terpajan. ${ }^{1,15}$ Antibodi yang cukup sudah timbul pada hari ke 3-6 setelah vaksinasi. ${ }^{1}$ Vaksinasi dapat diberikan pada pasien penyakit jantung, penyakit paru kronik, penyakit hati kronik, gagal ginjal, penyakit ginjal stadium akhir, hemodialisa, alkoholisme kronik, diabetes, asplenia, defisiensi komplemen, dan infeksi HIV dengan CD4 $\geq 200 \mathrm{sel} / \mu \mathrm{l} .{ }^{19}$ Kontraindikasi pada vaksinasi adalah kehamilan, imunokompromais (selain HIV), dan infeksi HIV dengan CD4 < 200 $\mathrm{se} / / \mu 1 .{ }^{19,20}$

Varicella zoster immunoglobuline (VZIG) diberikan kepada individu yang rentan (belum pernah terkena varisela), berisiko terjadi komplikasi, memiliki kontraindikasi vaksinasi, dan terpapar secara signifikan., ${ }^{3,15}$ VZIG dapat mencegah atau meringankan varisela yang berat pada kelompok yang rentan, bila diberikan dalam 
72-96 jam hingga 10 hari setelah pajanan secara intramuskular. ${ }^{2,3,7,21}$ Proteksi dari immunoglobulin ini bersifat sementara. ${ }^{2}$ Terapi antivirus profilaksis dapat digunakan untuk individu risiko tinggi yang tidak dapat divaksinasi atau sudah lebih dari 96 jam setelah kontak. ${ }^{3} \quad$ Penggunaan asiklovir, valasiklovir, atau famsiklovir dapat menurunkan keparahan penyakit tetapi tidak sepenuhnya mencegah penyakit. ${ }^{3}$

Pada ibu hamil, karena kontraindikasi terhadap vaksinasi, sehingga bila terpapar tanpa riwayat varisela sebelumnya dapat dilakukan pemeriksaan serologis varisela. ${ }^{11}$ Bila didapatkan hasil seronegatif, dapat diberikan VZIG. ${ }^{11,20}$ Virus dalam vaksin tidak disekresikan ke air susu ibu, sehingga vaksinasi saat postpartum tidak perlu ditunda karena menyusui. ${ }^{11}$ Sedangkan pada kondisi imunokompromais yang kontraindikasi terhadap vaksinasi, terapi antivirus untuk profilaksis juga dapat digunakan sebagai langkah tambahan selain pemberian VZIG. ${ }^{15}$

\section{Penutup}

Varisela pada dewasa, kehamilan, dan kondisi imunokompromais memiliki gejala yang lebih berat dan lebih sering terjadi komplikasi viseral dibandingkan dengan anak-anak. Sehingga perlu dilakukan pengobatan yang tepat dan upaya pencegahan dengan vaksinasi pada kelompok dewasa yang rentan.

\section{Daftar Pustaka}

1. Aisah S, Handoko RP. Varisela. Dalam: Ilmu penyakit kulit dan kelamin. 7th ed. Jakarta: Badan Penerbit FKUI; 2016. p. 128-31.

2. Levin MJ, Schmader KE, Oxman MN. Varicella and herpes zoster. In: Fitzpatrick's Dermatology. 9th ed. New York: McGraw-Hill Education; 2019.2 p. 3035,3036,3039,3041,3047,3048-56.

3. Whitley RJ. Varicella-zoster virus infections. In: Harrison's principles of internal medicine. 20th ed. New York: McGraw-Hill Education; 2018. p. 1354-7.

4. Daulagala SWPL, Noordeen F. Epidemiology and factors influencing varicella infections in tropical countries including Sri Lanka. Virus Disease. 2018;29(3):277-84.

5. Germinario C, Gallone MS, Cappelli MG, Tafuri S. Clinical benefits of routine varicella vaccination for adults. Hum Vaccines Immunother. 2015;11(6):1426-8.

6. Sondakh CC, Kandou RT, Kapantow GM. Profil varisela di poliklinik kulit dan kelamin RSUP Prof. Dr. R.D Kandou Manado periode januari - desember 2012. E-Clin [Internet]. 2015 Feb 10 [cited 2020 Aug 25];3(1). Available from: https://ejournal.unsrat.ac.id/index.php/eclinic/ article/view/6760

7. Kennedy P, Gershon A. Clinical features of varicella-zoster virus infection. Viruses. 2018;10(11):609.

8. Denny JT, Rocke ZM, McRae VA, Denny JE, Fratzola $\mathrm{CH}$, Ibrar $\mathrm{S}$, et al. Varicella pneumonia: case report and review of a potentially lethal complication of a common disease. J Investig Med High Impact Case Rep. 2018;6:232470961877023.

9. Singru S, Tilak V, Gandham N, Bhawalkar J, Jadhav S, Pandve H. Study of susceptibility towards varicella by screening for the presence of IgG antibodies among nursing and medical students of a tertiary care teaching hospital in Pune, India. J Glob Infect Dis. 2011;3(1):37.

10. de Valliere S, Cani N, Grossenbacher M, Puig F, Masserey E, Bodenmann P. Comparison of two strategies to prevent varicella outbreaks in housing facilities for asylum seekers. Int $\mathbf{J}$ Infect Dis. 2011;15(10):e716-21.

11. Cunningham FG, Leveno KJ, Bloom SL, Dashe JS, Hoffman BL, Casey BM, et al., editors. Infectious diseases. In: Williams Obstetrics. 25th ed. New York: McGraw-Hill Education; 2018. p. 1212,1213.

12. Bollaerts K, Riera-Montes M, Heininger U, Hens N, Souverain A, Verstraeten T, et al. A systematic review of varicella seroprevalence in European countries before universal childhood immunization: deriving incidence from seroprevalence data. Epidemiol Infect. 2017;145(13):2666-77.

13. Verleden GM, Vos R, Van Raemdonck DE, Laleman W, Vanaudenaerde BM. Acute liver failure due to Varicella zoster virus infection after lung transplantation: a case report. Transplant Proc. 2012;44(5):1457-9.

14. Trotta M, Borchi B, Niccolai A, Venturini E, Giaché S, Sterrantino G, et al. Epidemiology, management and outcome of varicella in pregnancy: a 20-year experience at the tuscany reference centre for infectious diseases in pregnancy. Infection. 2018;46(5):693-9.

15. Lachiewicz AM, Srinivas ML. Varicellazoster virus post-exposure management and prophylaxis: a review. Prev Med Rep. 2019;16:101016.

16. Nauka P, Hasan Z, Hilewitz A, Koenig S, Chen L, Gong J. Varicella pneumonia in an immunocompetent adult with interstitial lung disease (ILD) requiring veno-venous 
extracorporeal membrane oxygenation (VVECMO). Chest. 2019;156(4):A2053-4.

17. Saha B, Fless K, Yodice P, Mistry N, Rezai F, Ovnanian V. A case of deadly varicella pneumonia in an immunosuppressed patient. Chest. 2016;150(4):805A.

18. Gargouri S, Khochtali S, Zina S, Khairallah M, Zone-Abid I, Kaibi I, et al. Ocular involvement associated with varicella in adults. $\mathbf{J}$ Ophthalmic Inflamm Infect. 2016;6(1):47.

19. PAPDI. Jadwal imunisasi dewasa rekomendasi satgas imunisasi dewasa PAPDI Tahun 2017. PAPDI; 2017.
20. Shrim A, Koren G, Yudin MH, Farine D, Gagnon R, Hudon L, et al. Management of varicella infection (chickenpox) in pregnancy. J Obstet Gynaecol Can. 2012;34(3):287-92.

21. Levin MJ, Duchon JM, Swamy GK, Gershon AA. Varicella zoster immune globulin (VARIZIG) administration up to 10 days after varicella exposure in pregnant women, immunocompromised participants, and infants: Varicella outcomes and safety results from a large, open-label, expanded-access program. Borrow $\mathrm{R}$, editor. PLOS ONE. 2019;14(7):e0217749. 